\title{
SINTASAN, PERTUMBUHAN DAN VITALITAS LARVA IKAN BANDENG (Chanos chanos) YANG DIBERI PAKAN MIKRO
}

\author{
Ketut Suwirya*', Marzuqi ${ }^{*}$, Hersapto ${ }^{*}$ dan Agus Prijono*
}

\begin{abstract}
ABSTRAK
Produksi larva bandeng sampai saat ini sangat tergantung pada pakan alami seperti rotifer. Kekurangan nutrien akan menyebabkan mortalitas yang tinggi dan abnormalitas pada larva sementara ketersediaan pakan alami sangat dipengaruhi oleh kondisi alam. Untuk mengantisipasi penggunaan pakan buatan pada produksi larva telah dilaksanakan dua percobaan. Percobaan 1 menggunakan larva umur 15 hari dengan bak ukuran 30 liter dan kepadatan benih 4 ekor/L. Lama percobaan adalah 15 hari. Adapun perlakuannya adalah penggunaan pakan buatan dibandingkan dengan pakan alami. Hasilnya terlihat bahwa pakan buatan dapat meningkatkan sintasan dan vitalitas benih. Percobaan 2 menggunakan bak 1 ton dengan larva yang baru menetas (D-0) pada kepadatan 12.000 ekor/bak. Umur larva 1-10 hari diberi rotifer dengan kepadatan 10-40 ind./mL. Pada umur 11 hari mulai diberi pakan buatan dengan sumber protein berbeda yaitu A: tepung ikan; B: tepung ikan dan rebon, C: tepung ikan, rebon dan cumi; D: tepung ikan dan cumi. Hasil yang diperoleh menunjukkan bahwa sintasan dan pertumbuhan larva bandeng lebih tinggi jika diberikan beberapa sumber protein (pakan B, C dan D) dibandingkan hanya satu sumber yakni tepung ikan (pakan A).
\end{abstract}

\begin{abstract}
Survival, growth and vitality of milkfish, Chanos chanos larvae fed with micro diet. By: Ketut Suwirya, Marzuqi, Hersapto, and Agus Prijono.

At present, milkfish larvae production mostly depends on natural feed like rotifer. The availability of natural feed is affected by natural condition. Lack of nutrient could cause high mortality and abnormality of larvae, while to anticipate the use of micro diets in larvae production of milkfish, 2 experiment were conducted. Experiment 1 used 30-liter tanks, larvae 15 days old with stocking density of $4 \mathrm{pcs} /$ liter. The experiment lasted for 15 days. The treatment was the use of artificial feed compared to natural feed. The result showed that the use of artificial diet in larvae production could improve the survival rate and vitality of larvae. Experiment 2 used 1 ton tank, stocked with a density of 12,000 larvae/tank (at D-0). At the first 1-10 days, the larvae were fed, with rotifer at a density of 10-40 ind. $/ \mathrm{mL}$, and thereafter were fed artificial diets containing different protein sources i.e. fish meal (A), fish meal and tiny shrimp meal (B), fish meal, tiny shrimp meal and squid meal $(C)$, fish meal and squid meal (D). The result showed that survival and growth of larvae which were fed diet containing various protein sources $(B, C$, and $D)$ were better than the one fed only with fish meal $(A)$.
\end{abstract}

KEYWORDS: milkfish larvae, microdiet, growth.

\section{PENDAHULUAN}

Teknologi pembenihan ikan bandeng telah berhasil didapatkan, akan tetapi produksi benih ikan ini masih sangat bergantung pada pakan hidup seperti rotifer, Brachionus plicatilis. Teknologi ini membutuhkan banyak investasi dalam pembangunan fasilitas dan pemeliharaan untuk memproduksi pakan alami sesuai dengan kebutuhan. Produksi pakan alami sangat dipengaruhi oleh kondisi alam, dan kekurangan nutrisi akan menyebabkan mortalitas yang tinggi dan bentuk yang tidak sempurna dari benih yang dihasilkan. Oleh karena itu pakan buatan berupa pakan mikro penting sebagai substitusi pakan alami, untuk meningkatkan produksi benih yang digunakan dalam budi daya (Teshima et al., 1982, Kanazawa \& Teshima, 1988) dan meningkatkan kualitas benih yang dihasilkan (Hayashi, 1995). Pakan mikro untuk larva ikan yang perlu mendapatkan perhatian adalah sebagai berikut:

a. Ukuran diameter partikel 100-300 m dan stabil di dalam air hingga dimakan oleh larva.

b. Nutrisinya berimbang dan dapat dicerna oleh larva.

c. Ukuran partikel dan gravitasinya sesuai dengan perkembangan larva.

Pakan mikro untuk larva ikan dapat dikategorikan ke dalam tiga kelompok yaitu micro encapsulated, micro bound, dan micro coated. Pakan mikro yang dicobakan dalam percobaan ini

\footnotetext{
* Peneliti pada Loka Penelitian Perikanan Pantai Gondol
} 
adalah yang termasuk dalam kelompok micro bound. Secara umum, protein yang mempunyai komposisi asam amino yang sama dengan tubuh ikan mempunyai nilai nutrisi yang tinggi. Dalam pembuatan pakan dapat diformulasikan dari beberapa sumber protein untuk mensimulasikan komposisi asam amino yang sesuai dengan asam amino tubuh ikan. Sumber protein yang dapat digunakan pada larva ikan red sea bream adalah tepung ikan, cumi, krill, dan kerang (Kanazawa \& Teshima, 1988). Oleh karena itu untuk mengantisipasi formulasi pakan benih bandeng, dilakukan penelitian mengenai respon benih bandeng terhadap pakan buatan dan memformulasikan pakan dengan sumber protein kombinasi antara tepung ikan (sebagai sumber protein utama), cumi dan rebon.

\section{BAHAN DAN METODE}

\section{Percobaan 1}

Percobaan ini dilakukan untuk mengetahui respon larva ikan bandeng terhadap pakan mikro dibandingkan dengan pakan alami. Percobaan ini menggunakan bak silinder volume $30 \mathrm{~L}$ yang terbuat dari polietilin dan dilapisi plastik kuning dari luar, sehingga warna dinding bak menjadi kuning dari dalam. Warna bak yang kuning cocok untuk pemeliharaan larva bandeng. Pada percobaan ini digunakan larva umur 15 hari yang dipindahkan dari bak ukuran $3 \mathrm{~m}^{3}$. Kepadatan larva pada awal percobaan adalah 4 ekor/L. Adapun pakan mikro yang dipakai pada percobaan ini adalah pakan A seperti pada Tabel 1. Ukuran pakan yang digunakan adalah $125-250 \mu \mathrm{m}$ pada umur benih 15-19 hari dan 250-350 $\mu \mathrm{m}$ setelah umur benih > 20 hari.

Sisa pakan dan feses dibersihkan serta penggantian air $50 \%$ dilakukan setiap hari. Adapun pemberian pakan (feeding scheme) pada percobaan ini seperti pada Tabel 2. Pada pemeliharaan benih dengan menggunakan pakan mikro diberikan juga pakan alami dengan kepadatan $10 \mathrm{ind} . / \mathrm{mL}$ pada sore hari. Percobaan dilaksanakan menggunakan rancangan acak lengkap dengan dua ulangan.

\section{Percobaan 2}

Percobaan ini sebagai kelanjutan dari percobaan 1 dan dilaksanakan untuk mengetahui sumber protein yang sesuai dengan larva bandeng. Pada percobaan ini menggunakan bak serat kasar

Tabel 1. Komposisi pakan percobaan (\%).

Table 1. Composition of the test diets (\%).

\begin{tabular}{lrrrr}
\hline \multirow{2}{*}{ Bahan (Ingredients) } & \multicolumn{4}{c}{ Pakan percobaan (Test diets) } \\
\cline { 2 - 5 } & A & \multicolumn{1}{c}{ B } & C & D \\
\hline Tepung ikan (Fish meal) & 63.50 & 38.10 & 38.10 & 38.10 \\
Tepung rebon (Tiny shrimp meal) & 0.00 & 27.00 & 13.50 & 0.00 \\
Tepung cumi (Squid meal) & 0.00 & 0.00 & 13.50 & 27.00 \\
Kanji (Raw starch) & 8.00 & 8.00 & 8.00 & 8.00 \\
Tepung beras (Rice meal) & 2.40 & 2.40 & 2.40 & 2.40 \\
Vit. mix & 2.00 & 2.00 & 2.00 & 2.00 \\
Mineral mix) & 5.00 & 5.00 & 5.00 & 5.00 \\
Minyak cumi (Squid oil) & 4.00 & 4.00 & 4.00 & 4.00 \\
Minyak kedele (Soybean oil) & 2.00 & 2.00 & 2.00 & 2.00 \\
Lesitin (Lecithine) & 3.00 & 3.00 & 3.00 & 3.00 \\
Zein & 8.00 & 8.00 & 8.00 & 8.00 \\
Selulose (Cellulose) & 2.10 & 0.50 & 0.50 & 0.50 \\
Analisis (Analysis): & & & & \\
Protein kasar (Crude protein) & 39.50 & 40.30 & 41.20 & 40.70 \\
Lemak (Lipid) & 9.80 & 9.10 & 8.80 & 9.40 \\
\end{tabular}

1) Vitamin mix $(\mathrm{mg} / 100 \mathrm{~g}$ diet): Thiamine- $\mathrm{HCl} 5$, riboflavine 5, phyridoxine- $\mathrm{HCl} 4$, Cyanocobalamine 0.02 , nicotine 20, D-Calcium phantotenate 20, Choline chloride 300, DBiotine 0.4, inositol 200, folic acid 1.5, Menadion 2, B-carotene 0.3, Vit. E 10, Calciferol 10, p-aminobenzoic acid 25 , cellulose 1395.08 .

2) Mineral mix (mg/100 g diet): Fe-citrate 95,7, $\mathrm{MgSO}_{4} 215.77, \mathrm{~K}_{2} \mathrm{HPO}_{4} 774.6, \mathrm{NaH}_{2} \mathrm{PO}_{4} 281.4$, Ca-lactate 1005 . 
Tabel 2. Pemberian pakan selama pemeliharaan larva bandeng pada percobaan 1. Table 2. Feeding scheme of milkfish larvae at the first experiment.

\begin{tabular}{|c|c|c|c|}
\hline \multirow{2}{*}{$\begin{array}{l}\text { Umur larva } \\
\text { (hari) } \\
\text { Larval age } \\
\text { (day) }\end{array}$} & \multicolumn{2}{|c|}{$\begin{array}{l}\text { Pemberian pakan mikro dan pakan alami } \\
\text { Fed micro diet and natural food }\end{array}$} & \multirow{2}{*}{$\begin{array}{l}\text { Pemberian pakan } \\
\text { alami } 3 \text { kali per hari } \\
\text { Fed natural food } \\
\text { 3 times per day }\end{array}$} \\
\hline & $\begin{array}{c}\text { Pakan mikro per hari } \\
\text { Micro diet per day } \\
(\mathrm{mg})\end{array}$ & $\begin{array}{l}\text { Rotifer (ind./mL) } \\
\text { pukul } 16.00 \\
\text { Rotifer (ind. } / \mathrm{mL} \text { ) } \\
\text { at } 16.00\end{array}$ & \\
\hline $15-19$ & 600 & 10 & 30 \\
\hline $19-25$ & 1,700 & 10 & 40 \\
\hline $25-30$ & 2,000 & 10 & 50 \\
\hline
\end{tabular}

dengan volume $1 \mathrm{~m}^{3}$ yang berwarna kuning. Pakan buatan yang dicoba adalah pakan mikro A, B, C, dan D seperti pada Tabel 1. Larva bandeng yang digunakan adalah yang baru menetas (D-0). Kepadatan benih adalah 12.000 ekor per bak. Adapun cara pemberian pakan adalah seperti pada Tabel 3. Pergantian air dilakukan setiap hari sebanyak $50 \%$.

Peubah yang diamati pada percobaan 1 dan 2 adalah sintasan, pertumbuhan dan vitalitas dari benih pada akhir percobaan. Vitalitas larva ditentukan dengan cara sebagai berikut. Pada akhir percobaan larva diambil sebanyak 15 ekor dari setiap bak. Larva tersebut diletakkan pada saringan teh dan dibiarkan di udara selama 5 menit, setelah itu dikembalikan ke dalam bak 30 $\mathrm{L}$ yang berisi air laut serta dilengkapi dengan aerasi. Setelah 10 menit diamati jumlah larva yang masih hidup. Persentase larva bandeng yang masih hidup dinyatakan sebagai vitalitas larva bandeng. Data sintasan, pertumbuhan dan vitalitas dianalisis menggunakan ANOVA dengan selang kepercayaan $95 \%$.

\section{HASIL DAN BAHASAN}

\section{Percobaan 1}

Sintasan dan pertumbuhan pada percobaan 1 disajikan pada Tabel 4. Sintasan larva bandeng yang diberi pakan mikro lebih tinggi dibandingkan dengan hanya pakan alami $(\mathrm{P}<0,05)$. Dari hasil ini terlihat bahwa pemberian pakan mikro pada pemeliharaan benih bandeng dapat meningkatkan sintasan larva. Pertumbuhan larva bandeng tidak berbeda nyata $(\mathrm{P}>0,05)$ baik bila diberikan pakan alami maupun pakan buatan. Di samping itu vitalitas larva yang diberi pakan alami (rotifer) lebih rendah dibandingkan dengan benih yang diberi pakan buatan $(\mathrm{P}<0,05)$. Hal ini disebabkan oleh karena pakan alami kandungan nutriennya berfluktuasi tergantung pada kondisi alam (Kanazawa \& Teshima, 1988). Dengan penambahan pakan buatan maka kekurangan nutrien yang terdapat pada pakan alami dapat dipenuhi dari pakan buatan.

Tabel 3. Pemberian pakan larva bandeng selama pemeliharaan pada percobaan 2 .

Table 3. Feeding scheme of milkfish larvae at the second experiment.

\begin{tabular}{|c|c|c|c|c|}
\hline $\begin{array}{c}\text { Umur larva } \\
\text { (hari) } \\
\text { Larval age } \\
\text { (day) }\end{array}$ & $\begin{array}{c}\text { Pakan mikro } \\
\text { (gram/bak/hari) } \\
\text { Mikro diet } \\
\text { (gram/tank/day) }\end{array}$ & \multicolumn{3}{|c|}{$\begin{array}{c}\text { Rotifer } \\
\text { Natural fooo } \\
\text { (ind./mL) }\end{array}$} \\
\hline $2-5$ & & 10 & $\mathrm{x}$ & 3 \\
\hline $5-10$ & & $30-40$ & $\mathrm{x}$ & 2 \\
\hline $11-14$ & 4 & 10 & $\mathrm{x}$ & 1 \\
\hline $14 \cdot 18$ & 6 & 5 & $x$ & 1 \\
\hline $18-20$ & 8 & & - & \\
\hline
\end{tabular}


Tabel 4. Sintasan, pertumbuhan, dan vitalitas larva bandeng yang diberi pakan alami dan buatan.

Table 4. Survival rate, growth, and vitality of milkfish fry fed natural food and micro diet.

\begin{tabular}{lccc}
\hline $\begin{array}{l}\text { Perlakuan } \\
\text { Treatment }\end{array}$ & $\begin{array}{c}\text { Sintasan } \\
\text { Survival rate } \\
(\%)\end{array}$ & $\begin{array}{c}\text { Pertambahan bobot } \\
\text { Weight gain } \\
(\%)\end{array}$ & $\begin{array}{c}\text { Vitalitas larva } \\
\text { Vitality of larvae } \\
(\%)\end{array}$ \\
\hline $\begin{array}{l}\text { Pakan alami } \\
\text { Natural food }\end{array}$ & $75.7 \pm 3.32^{\text {a }}$ & $762.04 \pm 33.34^{\text {a }}$ & $56.67 \pm 5.77^{\text {a }}$ \\
$\begin{array}{l}\text { Pakan buatan } \\
\text { Micro diet }\end{array}$ & $88.4 \pm 8.98^{\mathrm{b}}$ & $753.85 \pm 32.63^{\text {a }}$ & $75.70 \pm 3.32^{\mathrm{b}}$ \\
\hline
\end{tabular}

Nilai rata-rata dalam kolom yang diikuti huruf yang sama tidak berbeda nyata (Mean values in the column followed by the same letter are not significantly different) $(\mathrm{P}>0.05)$

\section{Percobaan 2}

Sintasan larva bandeng lebih baik bila diberi pakan yang mempunyai lebih dari satu sumber protein. Pada Tabel 5 terlihat bahwa pakan A yang sumber proteinnya hanya tepung ikan memberikan sintasan 32,19 $\pm 3,21 \%$. Angka ini paling rendah jika dibandingkan dengan pakan yang disusun dari beberapa sumber protein (pakan B, C dan D). Di samping itu pertumbuhan benih yang diberi pakan yang mengandung lebih dari satu sumber protein (pakan B, C dan D) juga lebih baik dibandingkan pakan A yang sumber proteinnya hanya tepung ikan, walaupun vitalitas benih yang diberi keempat pakan buatan tidak berbeda nyata. $\mathrm{Hal}$ ini diperkirakan karena pakan buatan mempunyai nilai nutrisi yang lebih baik dibandingkan pakan alami. Dari laporan terdahulu ternyata asam dokosaheksaenoat (DHA) adalah lebih efektif daripada asam eikosapentanoat (EPA) sebagai lemak esensial (Takeuchi et al., 1990; 1992) dan meningkatkan vitalitas ikan red seabream dan stripe Jack (Watanabe et al., 1989). Di samping itu dijumpai bahwa rotifer yang dipelihara dengan N. ocalata tidak mengandung DHA (Watanabe et al., 1979). Dalam percobaan ini, pakan buatan yang digunakan mengandung minyak cumi, yang tentunya mengandung sejumlah DHA.

Sintasan larva udang, $P$. japonicus dipengaruhi oleh sumber protein pakan, karena keseimbangan asam amino esensial dari setiap sumber protein berbeda satu dengan yang lainnya. Oleh karena itu untuk mendapatkan keseimbangan asam amino esensial dari protein pakan maka sebaiknya disusun dari beberapa sumber protein (Koshio et al., 1992). Hal yang sama tampaknya juga terjadi pada larva bandeng, di mana kombinasi sumber protein tepung ikan, cumi, dan rebon pada pakan lebih baik sintasannya dibandingkan dengan pakan yang hanya mengandung satu sumber protein yaitu protein tepung ikan. Kekurangan

Tabel 5. Sintasan, pertumbuhan, dan vitalitas benih yang diberi pakan mikro dengan sumber protein berbeda.

Table 5. Survival rate, growth and vitality of larvae fed test diets formulated by different protein sources.

\begin{tabular}{cccc}
\hline $\begin{array}{c}\text { Pakan percobaan } \\
\text { Test diets }\end{array}$ & $\begin{array}{c}\text { Sintasan } \\
\text { Survival rate } \\
\mathbf{( \% )}\end{array}$ & $\begin{array}{c}\text { Pertambahan bobot } \\
\text { Weight gain } \\
\mathbf{( \% )}\end{array}$ & $\begin{array}{c}\text { Vitalitas } \\
\text { Vitality } \\
(\%)\end{array}$ \\
\hline A & $32.19 \pm 3.21^{\mathrm{a}}$ & $411.1 \pm 48.38^{\mathrm{a}}$ & $47.77 \pm 10.72^{\mathrm{a}}$ \\
$\mathrm{B}$ & $43.54 \pm 4.37^{\mathrm{b}}$ & $541.1 \pm 57.16^{\mathrm{b}}$ & $50.21 \pm 9.47^{\mathrm{a}}$ \\
$\mathrm{C}$ & $39.94 \pm 3.75^{\mathrm{b}}$ & $544.47 \pm 6.00^{\mathrm{bc}}$ & $55.42 \pm 7.82^{\mathrm{a}}$ \\
$\mathrm{D}$ & $38.48 \pm 0.66^{\mathrm{b}}$ & $677.8 \pm 112.75^{\mathrm{c}}$ & $53.26 \pm 63^{\mathrm{a}}$ \\
\hline
\end{tabular}

Nilai rata-rata dalam kolom yang diikuti huruf yang sama tidak berbeda nyata (Mean values in the column followed by the same letter are not significantly different) ( $P>0.05)$ 
asam amino pada satu bahan akan dilengkapi oleh asam amino dari bahan lain sehingga diharapkan terjadi keseimbangan asam amino esensial dari protein pakan.

\section{KESIMPULAN}

Dalam pemeliharaan larva ikan bandeng, pakan alami (rotifer) dapat disubstitusi dengan pakan buatan. Penambahan pakan buatan dalam pemeliharaan larva ikan bandeng dapat meningkatkan sintasan dan vitalitas dari larva. Di samping itu pakan buatan untuk larva ikan bandeng lebih baik apabila mengandung beberapa sumber protein seperti tepung ikan, rebon dan cumi.

\section{DAFTAR PUSTAKA}

Hayashi, M.. 1995. Growth, survival and vitality of red seabream, Pagrus major and japanese flounder, Paralichthys olivaceus, fry fed microbound diets. The Israeli Journal of aquaculture, 47: 119-128.

Kanazawa, A. and Teshima, S. 1988 Microparticulate diets for fish larvae. pp 57-61 In A.K. Sparks (Ed) New and innovative advance in biology/engineering with potential for use in aquaculture. Natl. Mar. Fish. Serv., Seatle.
Koshio, S., Kanazawa, A. and Teshima, S. 1992. Search for effective protein combination with crab protein for larval kuruma prawn, Penaeus japonicus. Nippon Suisan Gakkaishi, 58 (6): 1083-1089.

Takeuchi, T., Toyota, M., Satoh, S. and Watanabe, T. 1990. Requirement of juvenile red seabream, Pagrus major for EPA and DHA. Nippon Suisan Gakkaichi, 56:1263-1269.

Takeuchi, T., Arakawa, T., Satoh, S. and Watanabe, T. 1992. Supplemental effect of phospholipid and requirement of eicosapentaenoic acid and docosahexaenoic acid of juvenile striped jack. Nippon Suisan Gakkaishi. 58:707-713.

Teshima, S., Kanazawa, A. and Sakamoto, M. 1982. Micoparticulate diets for the larvae of aquatic animal. Min. Rev. Data File Fish. Res. 2: 67-86.

Watanabe, T., Oowa, F., Kitajima, C., Hujita, S. and Yano, Y. 1979. Relationship between the dietary value of rotifer, Brachionus plicatilis and their content of n-3 HUFA. Bull. Jpn. Soc. Sci. Fish., 45: 883-889

Watanabe, T., Izquierdo, M.S., Takeuchi, T., Satoh, S. and Kitajima, C. 1989. Comparation between EPA and DHA in terms of essential fatty acid efficacy in larvae red seabream. Nippon Suisan Gakkaishi, 55: 1635-1640. 